\title{
TAHITING DAWEN SAWANG
}

Fenomena Perlawanan Budaya di Kalimantan Tengah

Oleh. Joni Rusmanto

\begin{abstract}
Abstrak
Program dan kebijakan pembangunan di suatu masyarakat yang hanya mengejar target pertumbuhan ekonomi, serta mengabaikan pembangunan dalam aspek social budaya, kemungkinan dapat membuka ruang bagi timbulnya berbagai bentuk resistensi atau perlawanan social di masyarakat. Demikian halnya fenomena perlawanan budaya yang belakangan ini terjadi di setiap daerah, dapat dipandang sebagai respon kongkrit masyarakat lapisan bawah yang tidak setuju dengan kebijakan pembangunan yang dominatif dan memarginalitatif. Dinamika gerakan yang terjadi, baik yang bersifat perlawanan individual maupun aksi-aksi kolektif yang memobilisasi simbol-simbol budaya dan aksi penggalangan kekuatan sumber daya lainnya, dapat pahami sebagai bentuk aksi penolakkan dan ketidaksetujuan mereka terhadap system pembangunan yang tidak adil dan merata di daerah.
\end{abstract}

Kata kunci: pembangunan, target ekonomi, dominatif, dan resistensi social (social resistance).

\section{PENDAHULUAN}

\section{Latar Belakang}

Sejak bergulirnya undang-undang nomor 22 tahun $1999,{ }^{1}$ yang mengatur masalah desentralisasi dan otonomi daerah yang kemudian diberlakukan secara efektif sejak tahun 2001, telah memberikan otoritas baru bagi pemerintah daerah dalam konteks semangat local democratic model ke dalam kerangka sistem pemerintahan daerah agar lebih menekankan kepada prinsip-prinsip demokratisasi, peran serta masyarakat, pemerataan dan keadilan sehingga tercapainya pemberdayaan dan kemandirian rakyat di daerah otonomi (Koswara, Kertapradja, 2002;300). Sejak diberlakukannya otonomi dalam konteks pembangunan demokratisasi di daerah, telah mendorong semangat baru bagi pemerintah untuk mengelola sumber daya potensial yang dimiliki oleh setiap daerah.

Di Propinsi Kalimantan Tengah, pola kebijakkan pembangunan diarahkan untuk mengejar target agar tercapainya pertumbuhan ekonomi yang optimal bagi peningkatan kesejahteraan masyarakat di daerah. ${ }^{2}$ Pertumbuhan ekonomi dipandang relative masih rendah sehingga permasalahan inilah yang menjadi tugas dan tanggung jawab pemerintah dalam rangka mencari cara untuk meningkatkan laju pertumbuhan ekonomi dalam berbagai sektor potensial yang di miliki oleh masing-masing daerah.

Salah satu sektor potensial yang dikembangkan adalah membangun sistem regulasi dan mekanisme kebijakan politik pada bidang agraria yang bertujuan untuk mengatur serta mengelola permasalahan di seputar sumber daya hutan sebagai sumber pendapatan asli daerah (PAD). Dan perhatian ini kemudian telah memberikan kewenangan baru bagi pemerintah untuk mengeluarkan Peraturan Daerah (Perda) Propinsi Nomor 3 tahun 2003 tentang pengusahaan perkebunan (Lembaran Daerah Propinsi Kalimantan Tengah tahun

\footnotetext{
${ }^{1}$ Undang undang otonomi Nomor 22 Tahun 1999 ini kemudian direvisi ke dalam Undang-undang Nomor 32 Tahun 2004 tentang Pemerintahan Daerah.

${ }^{2}$ Sejak Undang-undang Otonomi Daerah diberlakukan secara efektif, maka pembagian secara administratif kewilayahan pemerintahan propinsi Kalimantan Tengah menjadi 13 Kabupaten dan 1 Kota.
} 
2003 Nomor 7 Seri E). Peraturan daerah tersebut dalam rangka untuk merumuskan Rencana Tata Ruang Wilayah Propinsi (RTRWP) Kalimantan Tengah tahun 2003 yang bertujuan untuk merumuskan serta menetapkan areal dan lokasi Kawasan Pengembangan Produksi (KPP).

Dalam rangka melaksanakan peraturan daerah tersebut di atas, pemerintah propinsi dan kabupaten telah merangkul steakholders agar mampu bekerjasama yang saling menguntungkan, dengan pihak pengembang asing maupun lokal dalam sektor pertambangan batu bara, emas dan perkebunan kelapa sawit. Kemudian pada akhirnya tidaklah terlalu mengherankan bahwa dikemudian hari, laju pertumbuhan ekonomi di sektor pertambangan dan perkebunan di Kalimantan Tengah dalam periode 2008-2011, mengalami peningkatan jumlah investasi yang cukup signifikan. Dengan demikian, untuk saat ini saja, sudah terdapat ratusan perusahaan pengembang dan pemilik modal yang menanamkan modal di sektor pertambangan dan perkebunan di setiap kabupaten di wilayah propinsi Kalimantan Tengah. ${ }^{3}$

Kehadiran pengembang dalam sektor pertambangan maupun perkebunan, bukanlah tanpa masalah, justru mendorong kepada upaya percepatan peningkatan eksploitasi sumber daya alam yang semakin tidak terkendali. Sehingga hal inilah yang kemudian menimbulkan masalah-masalah baru bagi kehidupan masyarakat di Kalimantan Tengah. Persoalan tersebut, pertama, pada aspek ekologis berdampak pada kerusakan lingkungan dan eksistensi kehidupan di dalamnya yang semakin terancam, kedua, terbukanya ruang konflik baru yang bersifat harisontal masyarakat versus Negara (kepentingan pengembang dan pemilik modal).

Demikian juga program pembangunan ekonomi dalam sektor pertambangan dan perkebunan, secara langsung tidaklah terlalu banyak memberikan dampak yang positif bagi peningkatan kesejahteraan masyarakat di daerah, bahkan sebaliknya justru menambah jumlah angka kemiskinan masyarakat di daerah pedesaan. ${ }^{4}$ Masalah lain yang juga muncul seperti misalnya peningkatan praktek-praktek formal upaya penguasaan dan perampasan hak-hak masyarakat atas tanah adat secara legal oleh Negara (kepentingan pengembang). Demikian juga dampak langsung yang dihasilkannya misalnya polusi atau pencemaran air sungai oleh limbah pabrik CPO (Cruid Palms Oils) serta pelanggaran situs-situs sakral budaya lokal dalam bentuk pembabatan areal hutan, lahan dan sekitarnya. (Draft Naskah Akademik Pengelolaan Sawit Berkelanjutan Kalimantan Tengah, 2008;22).

Oleh karena itu, sangatlah beralasan jika Marcus Colchester, Norman Jiwan dan kawan-kawan menjelaskan bahwa ekspansi perkebunan kelapa sawit memiliki dampak besar bagi penduduk Indonesia. Perluasan perkebunan kelapa sawit mengakibatkan pemindahan lahan dan sumber daya, perubahan luar biasa terhadap vegetasi dan ekosistem setempat, penanaman modal besar dan infrastruktur baru, perpindahan penduduk dan pemukiman, transformasi besar terhadap perdagangan lokal dan

\footnotetext{
${ }^{3}$ Berdasarkan data statistik Dinas Perkebunan Propinsi Kalimantan Tengah tahun 2008 hlm. 1, bahwa untuk tahun 2008 saja, terdapat 229 perusahaan sawit negara maupun swasta dengan luas areal pengembangan perkebunan sekitar 1.142.073,89 Ha dengan produksi rata-rata 6.669.474,13 Ton/CPO (Cruid Palm Oils).

${ }^{4}$ Untuk periode Maret 2010 s/d Maret 2011, Indeks Kedalaman Kemiskinan $\left(\mathrm{P}_{1}\right)$ lebih baik dari 1,018 menjadi 0,988. Ini mengindikasikan bahwa rata-rata pengeluaran penduduk miskin makin mendekatigaris kemiskinan. Indeks Keparahan Kemiskinan $\left(\mathrm{P}_{2}\right)$ menunjukkan kecenderungan naik dari 0,238menjadi 0,242. Angka ini menunjukkan bahwa ketimpangan pengeluaran penduduk miskin sedikit melebar dibanding tahun 2010. Sumber BPS Propinsi Kalimantan Tengah Tahun 2011 (Lebih lanjut lihat poin Tingkat Kemiskinan Kalteng tahun 2011 no 1/vii/Juli 2011).
} 
internasional serta memerlukan campur tangan berbagai lembaga pemerintah. Dilakukan dengan benar, minyak sawit menghasilkan kekayaan dan lapangan pekerjaan bagi masyarakat lokal. Sebaliknya, jika perkebunan kelapa sawit dikembangkan tidak dengan benar, dapat mengarah pada pengasingan lahan, hilang mata pencarian, konflik sosial, eksploitasi buruh dan kerusakan berbagai ekosistem. (Marcus Colchester, Norman Jiwan, dkk, 2006;11).

\section{RUANG LINGKUP PEMBAHASAN}

\section{Politik Agraria \& Kebijakan Pengelolaan Sumber Daya Hutan dan Alam}

Konflik seputar masalah agraria, antara warga sekitar versus pihak perusahaan perkebunan, tidaklah bisa dilepaskan dari sistem perkebunan skala besar yang merupakan urat akar dari konflik (Fajri Nailus, 2010;13). Di mana sistem perkebunan kelapa sawit yang tetap eksis merupakan warisan dari sistem perkebunan skala besar yang diterapkan oleh Kolonial Belanda. Konfik agraria terjadi akibat ketimpangan penguasaan dan kepemilikan serta pengelolaan dan pemanfaatan sumber-sumber agrarian. Secara sederhana ketimpangan dapat digambarkan segelintir manusia menguasai dan memiliki serta mengelola dan memanfaatkan sumber-sumber agrarian dalam hal ini tanah sampai ratusan ribu bahkan jutaan hektar, sedangkan di sisi lain jutaan orang hidupnya mengandalkan sepetak dua petak tanah dan kekayaan alam bahkan sebagainnya hanya mengandalkan tenaganya untuk bekerja di tanah orang lain.

Ketimpangan atas penguasaan, kepemilikan, pengelolaan dan pemanfaatan sesungguhnya adalah cerminan dari masih berlangsungnya monopoli atas sumber-sumber agraria yang dilakukan oleh segelintir orang. Celakanya, hingga saat ini tidak ada upaya yang serius untuk menghilangkan praktek monopoli atas sumber-sumber agraria ini walaupun kita sudah merdeka lebih dari 64 tahun, malah yang terjadi justru sebaliknya pelanggengan sistem monopoli dengan berbagai perundangan dan peraturan yang dibuat di dalamnya.

Marcus Colchester, Norman Jiwan dan kawan-kawan, menyebutkan bahwa negara Indonesia tidak memiliki ukuran yang jelas dalam mengamankan hak adat atas tanah dan hutan. Terlebih lagi, hanya sedikit peraturan dan ketentuan hukum di Indonesia yang mampu memfasilitasi penerapan persetujuan tanpa paksaan. Sebaliknya, model pembangunan, sistem administrasi maupun hukum di Indonesia tidak menghormati hak adat, memandulkan lembaga adat dan mendorong pengelolaan hutan yang top down yang melanggar norma-norma yang diakui secara internasional (Marcus Colchester, Norman Jiwan, dkk, 2006;40).

Bagi masyarakat petani tradisional (peladang berpindah), bahwa tanah atau lahan bekas perladangan (yang mereka sebut petak bahu) sebagai hak milik warga yang selanjutnya banyak direklaim atau diserobot pihak investor atau pengembang perkebunan dengan alasan bertujuan bagi sawit rakyat, adalah lahan yang kebanyakkan bersumber dari lahan adat dan budaya masyarakat. Dalam perspektif kebudayaan, keberadaan hutan yakni pertama secara ekonomi sebagai sumber matapencaharian hidup yang utama terutama bagi para peladang untuk bertani (malan manana, mambahu mahimba), berburu (mamandup) dan meramu hasil-hasil hutan (manggemur) dan lain sebagainya. Kedua, hutan secara ideology dipahami sebagai wilayah yang memiliki nilai-nilai spiritual, misalnya sebagai tempat pemakaman para leluhur yang sudah lama meninggal (sandung,sapundu),sehingga kawasan hutan demikian harus dipelihara serta dijaga kelestariannya. Paulus Florus, Stepanus Djuweng dan kawan-kawan menyatakan: 
hancurnya hutan alam, akan menghancurkan kita juga. Pengamatan ini yang tampaknya didukung oleh pembangunan selama dua puluh lima tahun yang lalu di Kalimantan, mengisyaratkan bahwa kehadiran atau ketiadaan kelestarian kebudayaan secara langsung tercerminkan oleh kehadiran atau ketiadaan kelestarian di alam. Hal tersebut mengisyaratkan terdapatnya suatu kesatuan dan jalinan nasib antara manusia dengan lingkungan hidup mereka. (Paulus Florus, Stepanus Djuweng, dkk, 1994;xxxi)

Dalam kebiasaan masyarakat petani tradisional (peladang berpindah), bahwa tradisi membuka hutan sebagai lahan baru (himba) dilakukan secara turun temurun dalam setiap generasi. Kebiasaan berladang secara tradisional menjadikan para petani tersebut dapat memiliki banyak areal bekas ladang yang mereka sebut bahu. Menurut Hj. Irene, S. Jacobus E. Frans L. dalam Paulus Florus, dkk, 1994:91),bahwa berbagai jenis tanaman yang ditanam warga di atas bekas lahan atau ladang mereka adalah jenis tanaman yang mengandung nilai ekonomi tinggi yang diperuntukkan bagi sumber cadangan untuk mata pencaharian mereka di kemudian hari.

Bahu atau bekas areal ladang yang pernah dikelola oleh masyarakat, sebenarnya lahan yang tidak ditinggalkan begitu saja, melainkan secara social dan kultural menjadi hak milik warga masyarakat yang pada awalnya pernah menjadikan lahan tersebut untuk berladang. Legalitas social cultural ini sudah lama melekat dan lazimnya diterima oleh kalangan masyarakat petani tradisional di Kalimantan.

Di samping sebagai sumber cadangan untuk mata pencaharian dan tanaman- tanaman tersebut di atas untuk jangka panjang sebagai bentuk penegasan sosial kultural bahwa bahu atau bekas areal perladangan tersebut secara adat merupakan hak milik seseorang. Namun rupanya pengakuan kultural warga atas bekas lahan berladang atau bertani semacam ini, tidak diterima dalam perspektif logika hukum negara mengenai tata kelola dan pengaturan hukum pertanahan di Negara Indonesia. Seperti yang dikemukakan Sholih Mu'adi, bahwa konsep adat yang mengacu pada kepemilikan turun temurun yang didasarkan pada sejarah terjadinya hak garapan atas tanah tersebut dan kemudian harus beralih menjadi hak milik, dan hal itu bertentangan dengan konsep Barat (civil law) yang dianut pemerintah selama ini yakni kepemilikan secara formal yang mendasarkan pada konsep domein verklaring dan tidak mengenal adanya okupasi dalam hukum formal. Menurutnya fakta inilah yang kemudian menimbulkan sengketa tanah perkebunan yang dimaksudkan untuk menunjuk siapa yang paling berhak atas tanah tersebut (Sholih Mu'adi, 2010:37).

\section{Gerak Pertarungan dalam Dunia Keseharian}

Keberadaan perusahaan perkebunan besar sawit (PBS) dan pertambangan besar dan kecil yang masuk di daerah pedesaan, bukanlah tanpa masalah, justru telah mendorong percepatan perubahan sosial, ekonomi dan budaya. Terutama dalam aspek lingkungan hidup, perubahan itu telah meningkatkan upaya percepatan eksploitasi sumber daya alam dan hutan yang semakin tidak terkendali. Selain berdampak negatif bagi masa depan lingkungan, perubahan itu juga mengakibatkan semakin tertutupnya akses masyarakat kepada pengelolaan sumber daya hutan secara langsung.

Bagi orang Dayak yang masih mengandalkan mata pencaharian pada sumber daya hutan, keadaan ini berdampak kepada sumber pendapatan dan penghasilan ekonomi mereka sehari-hari. Pada akhirnya warga masyarakat di pedesaan semakin dimarginalitaskan ketergantungannya dengan sumber daya hutan. Ketersingkiran warga 
Dayak setempat terhadap akses pengelolaan sumber daya hutan dan alam yang dimonopoli oleh pihak-pihak tertentu, menjadikan mereka tetap berupaya bagaimana membangun serta menciptakan berbagai bentuk strategi agar tetap bertahan dan eksis di kampong halaman mereka (lewu).

Untuk memenuhi kebutuhan hidup sehari-hari, mereka bekerja sebagai penambang rakyat tradisional (istilah warga manyedot). Walaupun sebenarnya, kebanyakan dari pekerjaan ini mengandung banyak resiko, dari segi penghasilan dan pendapatan yang diperoleh pun terkadang tidak menetap, kadang-kadang mendapatkan keuntungan, namun kadang-kadang juga tidak mendapat hasil sebagaimana yang diharapkan. Namun resiko terburuk yang selalu dihadapi adalah berbagai aksi razia dari aparat kepolisian setempat, karena para penambang tradisional ini oleh Negara dianggap tidak mengantongi izin resmi untuk menambang sehingga mereka disebut penambang tanpa ijin PETI atau menurut istilah petugas hukum disebut illegal minning. ${ }^{5}$

Demikian juga dampak langsung dirasakan oleh para peladang (petani tradisional yang berpindah-pindah lahan garapan), lahan baru semakin sulit didapatkan karena lahan yang baru (himba) kebanyakan sudah ditetapkan sebagai kawasan KP, HGU, HPH, IUP, IUPR dan WIUPR. Wilayah hutan tersebut, dikonversikan sebagai pilot project kawasan hutan produktif yang bernilai ekonomi cukup tinggi, secara potensial dimanfaatkan untuk pembangunan proyek perkebunan kelapa sawit dan penambangan emas, batu bara dan pertambangan zat mineral lainnya.

Walaupun adanya lahan untuk berladang, dalam mengolah lahan untuk ladang pun tidak sembarangan, karena pemerintah melarang membuka ladang dengan cara- cara tradisional misalnya dengan membakar lahan, karena dapat menimbulkan bahaya kebakaran hutan. ${ }^{6}$ Adanya larangan ini pada akhirnya menjadikan masyarakat petani tradisional melakukan pembakaran ladang dengan aksi dan cara diam-diam bahkan secara sembunyi-sembunyi. ${ }^{7}$ Bagi warga desa yang dominan pekerjaannya sebagai petani tradisional, larangan untuk tidak membakar lahan, secara tidak langsung berarti melarang mereka untuk berladang. Dalam pemahaman warga desa, yang sumber

\footnotetext{
${ }^{5}$ Biasanya aparat gabungan selalu menggelar razia lapangan terhadap para penampang ilegal yang beraktivitas di setiap aliran sungai (DAS) Kahayan, Sungai Kapuas, dsbnya. Bagi para penambang tradisional tidak ada pilihan lain, kecuali tetap melakukan pekerjaan ini. Salah satu strategi agar tetap bertahan, para penambang liar ini berpindah lokasi penambangan secara diam-diam, yang semula dari sekitar aliran sungai, kini berpindah ke tepi daratan yang jauh dari jangkauan dan pengamatan para petugas di lapangan.

6 Disetiap musim kemarau tiba setiap tahun, bencana kabut asap tebal selalu menjadi permasalahan utama di Kalteng, polusi udara berdampak pada penyakit ISPA, mengganggu sistem perekonomian, lalu lintas udara (dunia penerbangan), sekolah banyak diliburkan, dsbnya. Yang menarik, ada anggapan kabut asap disebabkan oleh pembakaran lahan (pembukaan ladang berpindah) yang dilakukan oleh warga setempat. Padahal, tradisi berladang dengan cara tradisional (termasuk membakar terbatas), sejak jaman nenek moyang, tidak pernah mengakibatkan sampai munculnya bencana kabut asap sebagaimana yang selalu terjadi pada akhir-akhir ini. Justru mengapa kabut asap mulai terjadi sejak tahun 2008, seiring maraknya aksi legal pembukaan lahan bagi areal perkebunan sawit yang juga dilakukan dengan cara-cara membakar.

${ }^{7}$ Terdapat peraturan daerah pemerintah propinsi Kalimantan Tengah dalam mengatur masalah pengelolaan serta larangan mengenai lahan garapan baik untuk berladang maupun pembukaan areal perkebunan terbatas. Namun yang menarik perda itu di lapangan oleh aparat direduksi menjadi larangan terbatas hanya diberlakukan bagi pembukaan ladang warga masyarakat yg bertani secara tradisional. Sedangkan untuk proyek pembukaan areal kelapa sawit perda itu seakan-akan tidak berlaku. Banyak kasus warga ditangkap hanya gara-gara tidak mengurus ijin dari RT, Kelurahan atau Kecamatan hingga ke Kepolisian untuk membakar sepetak dua petak lahannya untuk berladang. Bagi warga pengurusan ijin terlalu merepotkan, biaya keluar banyak, membutuhkan waktu lama untuk menunggu, prosedural, sehingga aksi diam-diam membakar lahan pun menjadi keharusan, seperti membakar lahan malam hari tapi kemudian ditinggalkan begitu saja, untuk menghindari tanggungjawab langsung di lapangan.
} 
penghasilan mereka hanya tergantung pada hasil bertani atau berladang, larangan itu sama saja artinya melarang mereka untuk makan, secara tidak langsung tidak memperbolehkan mereka untuk melanjutkan kehidupan mereka sehari-hari.

Begitu juga kesulitan ini dialami secara langsung bagi mereka yang usahanya mengandalkan dan meramu hasil-hasil hutan, memanfaatkan kayu untuk kebutuhan sendiri atau untuk dijual kepada orang lain walaupun tidak seberapa jumlahnya, jika tidak mengantongi ijin formal dari instansi terkait dianggap melanggar hukum (illegal loging). ${ }^{8}$ Konsekuensi yang terakhir ini, ada semacam resistensi kesadaran dalam pikiran warga dalam upaya untuk mengatasinya, yakni mengangkut kayu dari hutan secara sengaja pada siang hari bahkan juga dengan cara tersembunyi pada malam hari, dengan alasan untuk menghindari para petugas razia di lapangan. Mereka yang bermata pencaharian ini, tentu saja telah memperhitungkan kendala-kendala dan segala resiko yang kemungkinan dihadapi di lapangan.

Strategi dan aksi diam-diam dan aksi sengaja secara sembunyi-sembunyi adalah bentuk aksi perjuangan yang efektif dalam rangka untuk mempertahankan hidup sehingga tidak kehilangan sumber mata pencaharian yang mereka andalkan dalam kehidupannya.

Dapatlah dibayangkan bahwa apa yang dihadapi dalam realitas rutinitas dunia keseharian para warga dalam berjuang untuk mempertahankan hidup, sangatlah kontras dengan realitas di sekitar mereka. Manakala aktivitas legal formal pembukaan lahan perkebunan sawit beribu-ribu hektar, tidaklah dianggap merusak hutan, walaupun terkadang pengelolaan hutan pun secara biasa dilakukan dengan cara-cara yang tidak lebih beradab dan tradisional (misalnya membabat, menggundul isi hutan sampai habis bahkan juga dengan cara membakar).

Demikian juga, manakala, sumber daya alam di sekitar mereka di eksploitasi secara besar-besaran oleh mega proyek pertambangan emas dan batu bara milik negara maupun asing, dipandang tidak merusak lingkungan atau illegal mining. Strategi untuk bertahan hidup dalam situasi yang demikian, masih akan terus dilakukan oleh warga, bahkan menjadi sebuah keharusan dan bukanlah pilihan, dan upaya ini akan terus berlangsung selama proses distribusi dan akses pengelolaan tanah dan sumber daya hutan itu masih dibiarkan saja dimonopoli oleh segelintir orang atau pihak-pihak tertentu dalam masyarakat.

Memang benar drama kehidupan seperti ini selalu dihadapi oleh manusia dalam hidupnya. Michel de Certeau dalam, The Practice of Everyday Life (1988), mengatakan bahwa kehidupan sehari-hari terbentuk oleh aksi pelanggaran terhadap hak milik yang lain berlangsung dalam sekian banyak cara. Dan pandangan ini tampaknya memang didasarkan pada cara hidup yang alami. Dunia kehidupan ini merupakan habitat bagi semua makhluk, bagi inang hama dan bagi mangsa predator. Drama kehidupan di alam bereplikasi dalam drama sosial di alam kehidupan nyata, yaitu alam kehidupan keseharian manusia (Michel de Certeau, 1988: hlm, xii).

Singkat kata, berbagai bentuk aksi yang dilakukan warga dalam dunia keseharian tidak lain merupakan sebagai bentuk pertarungan dalam rangka untuk mempertahankan eksistensi kehidupan. Aksi yang harus dilakukan dalam situasi atau kondisi dinamika

\footnotetext{
${ }^{8}$ Banyak kasus yang ditangani polda Kalteng berkaitan dengan illegal loging, dan tidak sedikit pula warga desa biasa yang mengangkut kayu untuk keperluan membangun rumah sendiri, atau menjualnya dalam jumlah skala kecil (misalnya 1-2 kubik), ditangkap dan dijebloskan ke penjara hanya gara-gara tidak mengantongi ijin pengelolaan, pengangkutan dan penjualan secara legal dari dinans dan aparat terkait.
} 
hidup yang semakin sulit yang dialami oleh warga, terutama bagi mereka yang masih tetap menggantungkan sumber matapencaharaian utama pada sumber daya hutan dan sumber daya alam sekitar.

Sistem monopoli dan dominasi pengelolaan hutan dan lahan oleh pihak-pihak elit negara, hanya lebih mengutamakan kepentingan kekuatan para pengembang dan pemilik modal daripada kepentingan warga sekitar. Dan sistem ini, berakibat buruk bagi masa depan warga sehingga munculnya berbagai aksi dan gerakan perlawanan budaya tahiting yang akhir-akhir ini banyak terjadi di Kalimantan Tengah, dapat dipandang sebagai wujud protes dan aksi perlawanan masyarakat dalam menentang sistem kebijakan dalam pengelolaan agrarian yang tidak memihak.

\section{Fenomena Aksi Perlawanan dalam Tataran Simbolis}

Fenomena mobilisasi budaya tahiting yang akhir-akhir ini muncul di tengah-tengah masyarakat, mengindikasikan adanya potensi rivalitas dan resistensi masyarakat Dayak terhadap sistem pembangunan sumber daya alam yang tidak lagi keberpihakkan kepada mereka sebagai warga asli yang tinggal di daerah mereka sendiri. Dalam kondisi di mana pola dan sistem kebijakan pemerintah daerah dalam pengelolaan dan pendistribusian serta pemanfaatan lahan dan hutan dan sumber dayanya yang kurang terlalu memperdulikan kepentingan warga sekitar. Dan sebaliknya kebijakan negara justru lebih megutamakan kepentingan para pemilik modal dan pemegang saham dalam jaringan coorporate, yang kemudian mengakibatkan orang Dayak semakin disingkirkan dari wilayah mereka sendiri. Pemarginalan sistematis ini yang dalam istilah liguistik mereka sebagai symbol bahasa dunia sehari-hari mereka yakni; "tempun petak manana sare, tempun uyah batawah belai, tempun kajang bisa puat" (yang artinya memiliki tanah luas namun terbatas untuk berladang dan memiliki banyak kekayaan sumber daya hutan, namun menjalani hidup semakin susah di kampung sendiri).

Bagi masyarakat dalam menuntut keadilan dan hak-hak mereka atas tanah yang dirampas oleh pihak pengembang, berbagai cara yang telah dilakukan warga termasuk melakukan aksi perlawanan manahiting atau tahiting dawen sawang. Aksi manahiting adalah aksi kolektif menempatkan diri secara diam-diam atau secara sengaja menduduki areal lahan perkebunan yang disengketakan oleh kedua belah pihak. Dengan cara menghalangi atau membuat portal di tengah jalan, sambil melakukannya dengan adat ritual. Pemancangan rotan secara adat bersifat simbolis menandakan tapal batas antara kedua sisi atau wilayah dari pihak yang bersengketa, yaitu antara warga yang dirugikan dengan pihak perusahaan yang dianggap merampas hak-hak mereka atas tanah adat yang diambil alih oleh pihak pengembang dan pemiliki modal.

Menurut warga, melakukan tahiting di lokasi lahan yang disengketakan, dimaksudkan agar perusahaan memperhatikan tuntutan mereka, tidak mengabaikan permintaan warga agar diselesaikan dengan cara-cara adat seperti duduk bersama secara kekeluargaan, bermusyawarah untuk mencapai mufakat. Jika tahiting itu dilanggar (tali rotan yang dipasang ditengah jalan dalam areal perkebunan) secara sengaja oleh pihak lawan, berarti dianggap sebagai pihak yang menentang adat (melanggar pali). Pihak perusahaan yang secara sengaja memutuskan tali rotan yang dipasang (tahiting) oleh warga, akan dikenakan sanksi adat atau denda adat yang diatur dalam mekanisme adat masyarakat setempat. ${ }^{9}$

\footnotetext{
${ }^{9}$ Dalam pemahaman warga, memutus tali tahiting (rotal) dengan sengaja, secara simbolis sebagai bentuk pelanggaran yang tegas dan keras. Dan pelanggaran simbolis ini telah memperkuat dari adanya
} 
Dalam aksi ini, dilengkapi dengan berbagai atribut simbolis, yang menandakan bahwa kegiatan ini memiliki arti tersendiri bagi mereka yang melaksanakannya. Atribut simbolis yang digunakan seperti daun sawang, buah pepaya, beras ketan putih, telur ayam kampung dan satu ekor ayam kampung. Semua kelengkapan ini setelah kegiatan ritual dilaksanakan, semua peserta aksi tahiting gerakan bersama-sama berangkat menuju ke tengah areal perkebunan untuk memasang alat-alat simbolis (memancang) tali rotan yang melintang lurus sepanjang jalan, sambil diolesi dengan sebuah tulisan kecil berwarna putih bergambar salib yang bertuliskan dari bahan kapur sirih berwarna putih. Sesuatu yang dipergunakan sebagai kelengkapan atribut simbolis dalam aksi ini adalah bahan material yang mencerminkan sumber utama bersifat simbolik sebagai representasi makna realitas kehidupan mereka dengan eksistensi alam sekitar.

Menurut James, C Scott, berbagai atribut simbolis yang dilibatkan dalam aksi semacam ini, yang representasinya sumber-sumber kebutuhan dari alam sekitar mereka, adalah menandakan sebuah utopia yang dibayangkan mencakup suatu kehidupan di alam yang dapat dibayangkan oleh watak manusia yang berubah secara radikal tanpa mengandung keserakahan, iri hati dan kebencian, eksploitasi, dominasi, dsbnya. Sementara utopia profan ini juga merupakan antisipasi atas masa depan, ia sering mengingatkan kembali pada suatu mitos Taman Firdaus yang telah ditinggalkan manusia. Bukan lah berlebihan untuk melihat dalam ideologi yang biasa menurut sejarah, suatu pemberian simbolisme religius revolusioner demi kepentingan kelas. kemudian tidaklah mengherankan jika Scott mengatakan bahwa aksi pada tataran simbolik ini merupakan bentuk perlawanan dalam pikiran (ideologi) (James C.Scott, 2000:434).

Aksi simbolik manahiting yang dilakukan oleh warga, akan berakhir setelah pihak yang memiliki kepentingan (pengembang/perusahaan), berupaya mematuhi dan memenuhi harapan dan keinginan warga menyangkut segala hak-hak adat mereka atas lahan yang dirampas oleh perusahaan. Biasanya pihak pengembang dituntut mengganti kerugian secara materil berdasarkan kesepakatan bersama dengan pihak warga yang merasa dirugikan terhadap hak-hak adat atas lahan masyarakat yang diambil alih pihak perusahaan.

Secara teknis, bahwa rentetan aksi yang dilakukan warga termasuk memobilisasi alat budaya, dapat dipandang sebagai bentuk aksi protes dan perlawanan individual maupun kolektif yang rasional, di mana aksi ini kerabkali dilakukan di atas lahan perkebunan yang disengketakan kedua belah pihak. Dengan memancangkan tali rotan di areal yang disengketakan secara implisit menandakan upaya-upaya menduduki bahkan menghalangi sekaligus pemboikotan di atas lahan perkebunan selama mungkin sampai pihak warga merasa aksi itu sudah tidak perlu lagi dilakukan ketika pihak perusahaan telah memenuhi keinginan dan harapan mereka.

Warga setempat berpandangan bahwa apabila perusahaan perkebunan mengganggu kegiatan dan aksi manahiting warga di atas lahan maka konsekuensi logis dari tindakan itu bisa saja pihak yang melanggar akan didenda adat, namun bisa juga selanjutnya mengarah kepada aksi-aksi yang lebih reaktif. Pada tindakan yang terakhir 
ini sebagaimana yang telah terjadi di wilayah Kabupaten Kotawaringin Timur (Kotim) dan Seruyan, di mana aksi penjarahan dan kasus pencurian yang marak terjadi akhirakhir ini merupakan puncak dari akumulasi kekecewaan warga terhadap perusahaan PT. Wilmar yang berada di wilayah kabupaten Kotawaringin Timur dan Kabupaten Seruyan. Maraknya aksi pencurian dan penjarahan buah tandan sawit oleh warga di dua Kabupaten tersebut merupakan buntut aksi protes mereka sebelumnya yang tidak tercapai dan terpenuhi di dalam menuntut hak-hak mereka atas lahan adat yang dirampas oleh pihak PBS (Perusahaan Besar Sawit). (Kalteng Post, Senin 22 Juli 2013, hal. 8).

Perjuangan warga desa melalui aksi tahiting, dalam menuntut keadilan atas perampasan tanah sepihak, dapat dipandang sebagai bentuk gerakan perlawanan diri secara simbolis. Aksi gerakan bersifat simbolis yang dilakukan oleh warga, dalam tataran pikiran dan gagasan reaktif dan transformatif yang secara khusus dimaknai sebagai bentuk kesadaran rasional yang diwujudkan dalam gerakan aksi penolakan terhadap sistem dominasi dan monopoli yang sedang mereka hadapi dalam kehidupan nyata mereka seharihari. Gerakan perlawanan pada tataran simbolis inilah yang disebut Scott perlawanan sebagai pemikiran dan simbol dari mahkluk binatang yang dapat berfikir dan berjiwa sosial, yang tidak dapat dikesampingkan dalam kesadaran manusia, yaitu makna yang mereka berikan pada tindak tanduk mereka. Menurutnya, simbol, norma dan bentuk- bentuk ideologis yang mereka ciptakan merupakan latar belakang yang tidak dapat dihilangkan dari perilaku mereka (James C.Scott, 2000:51).

\section{Penutup dan Kesimpulan}

Perlawanan sebagai aksi gerakan yakni mengungkapkan suatu tipe aksi sosial yang dilakukan dengan ekspresi dan cara-cara yang lebih terselubung dan tersembunyi secara laten. Gerakan ini sifatnya relatif tidak menentu dan permanen bahkan terkadang lebih fleksibel dan tersembunyi secara implisit.

Banyak dari kontradiksi bermunculan di kalangan para penduduk desa yang lebih miskin dan yang secara ekonomi bergantung yang secara longgar bisa disebut sebagai petani kecil atau lapisan masyarakat bawah yang tersubordinasi. Bentuk-bentuk perlawanan dari kaum yang tak berdaya ini termasuk misalnya aksi-aksi menyerobot, menyeludupkan barang, masuk wilayah orang lain tanpa ijin, melakukan pembakaran, menyebarkan desasdesus, melakukan sabotase, melanggar hukum debngan sengaja dan sebagainya. Teknikteknik tersebut merupakan teknik-teknik —alternatif utamall (first resort) dalam situasisituasi di mana perlawanan terbuka tak mungkin atau berbahaya untuk dilakukan (James C. Scott, 1989:5).

Ketika teknik-teknik tersebut dilakukan secara lebih luas oleh anggota-anggota dari seluruh kelas melawan elit atau negara, teknik-teknik itu akan menghasilkan efek agregat yang jauh melampui efek yang dihasilkan jika dilakukan sendirian. Menurut Scott ada tiga konsekuensi umum dari model perlawanan semacam itu: pertama; perilaku perlawanan tersebut memberikan rasa kaya (a sense of welfare) di kalangan petani kecil. Kedua; perilaku perlawanan tersebut turut mengikis prinsip-prinsip normatif yang mendukung struktur dominasi. Dan ketiga; bentuk-bentuk perlawanan sehari-hari dari para petani kecil menjadi dasar bagi ekspresi aksi politik terbuka dari pihak mereka.

Kebanyakan bentuk manifestasi dari aksi kolektif yang bersifat terbuka dan terangterangan seperti revolusi, huru-hara, pemberontakan (rebels) dan gerakan-gerakan sosial, memiliki sejarah tersendiri. Dalam fase inkubasinya, aksi-aksi kolektif yang bersifat 
konfliktual ini pada umumnya tumbuh dan matang secara laten, tak nampak dan tersembunyi.

Seni perlawanan kaum tani modus-modus protes secara diam-diam di pedesaan yang berlangsung secara luas melawan pihak musuh, entah itu kelas dominan yang berkuasa atau kaum kaya di pedesaan, menandai proses berkembangnya penggambungan aksi-aksi yang tampaknya bersifat individual, diskursif dan tak terorganisir. Menurut Scott bahwa aksi-aksi terakhir inilah yang pada akhirnya sangat berbahaya yang bisa menjadi syarat meletusnya konflik secara terbuka (James C. Scott, 1989:6).

\section{Daftar Pustaka}

Certeau, Michel de. 1988. The Practice of Everyday Life, London: University of California Press.

Colchester, Marcus dan Jiwan, Norman, Andiko, dkk. 2006. Tanah yang Dijanjikan; Minyak Sawit dan Pembebasan Tanah di Indonesia, Implikasi Terhadap Masyarakat Lokal dan Masyarakat Adat. Jakarta: Forest Peoples Programme,Perkumpulan Sawit Watch, HuMA dan the World Agroforestry Centre.

Florus, Paulus dan Djuweng, Stephanus. 1994. Kebudayaan Dayak; Aktualisasi dan Transformasi. Jakarta: kerjasama LP3S-Institut of Dayakology Research and Development dengan penerbit PT. Gramedia Widiasarana Indonesia.

Kertapradja, E. Koswara, 2002. Otonomi Daerah; Untuk Demokrasi \& Kemandirian Rakyat. Jakarta: PT. Candi Cipta Paramuda.

Mu'adi, Sholih, 2010. Penyelesaian Sengketa Hak Atas Tanah Perkebunan dengan cara Litigasi dan Non Litigasi. Jakarta: Prestasi Pustakaraya.

Nailus, Fajri. 2010. Konflik Agraria di Perkebunan Kelapa Sawit, _Praktek Monopoli Perkebunan Kelapa Sawit Menjadi Dasar Konfik Agraria dan Konflik Sosial Lainnyal, dalam Buletin TANDAN SAWIT Edisi I/Februari 2010, Pusat Informasi Kampung (PIK) Tempat Baca dan Diskusi Warga Desa. Bogor: Penerbit Kumpulan Sawit Watch Bogor.

Pokja Sawit Multipihak Pemerintah Propinsi Kalimantan Tengah 2008 dalam Draft Naskah Akademis Pengelolaan Perkebunan Kelapa Sawit Berkelanjutan di Kalimantan Tengah Tahun 2008.

Scott, James, C. 1985. Weapons of the Weak: Everyday Forms of Peasant Resistance. New Haven: Yale University Press. (di Indonesia diterjemahkan menjadi, Senjatanya Orang-orang yang Kalah, oleh A. Rahman Zainuddin, dkk. Jakarta: Yayasan Obor Indonesia, 2000).

1989. 'Everyday Form of Resistance', in Forrest D. Colburn (ed.), Everyday Form of Peasant Resistance. New York, London: M.E. Sharpe. 1990. Domination and the Arts of Resistance: Hidden Transcripts. New Haven and London: Yale University Press.

Scott, James, C. and Benedict J. Tria Kerkvliet. 1986. "Some Issues in Everyday Forms Peasant Resistance” in South-East Asia', Journal of Peasant Studies, vol. 13, no. 2.

Santoso, Urip. 2012. Hukum Agraria: Kajian Komprehensif. Jakarta: Kencana Prenada Media Group.

Ukur, Fridolin. 1991. Tantang-Djawab Suku Dajak; suatu penjelidikan tentang unsur- unsur jang menjekitari penolakan dan penerimaan Indjil; dikalangan suku-Dajak dalam rangka Sedjarah Geredja di Kalimantan; 1835-1945 (Disertasi, Sekolah Tinggi Theologia Djakarta, 1971, diterbitkan. Jakarta: BPK Gunung Mulia. 
Koran Kalteng Post, Senin 22 Juli 2013, hal. 8. 